\title{
О ПРОИСХОЖДЕНИИ ПРАВА НА ДРЕВНЕЙ РУСИ В КИТАЙСКИХ ИССЛЕДОВАНИЯХ ${ }^{1}$
}

\begin{abstract}
ON THE ORIGIN OF THE RIGHT IN ANCIENT
RUSSIA IN CHINESE STUDIES
Yue Qiang

Summary. After reviewing more than 200 representative studies of legal literature, starting from the 19th century, concerning the study of the origin of law in Ancient Russia, it can be noted that scientists focused on four points: the study of literature on law in Ancient Russia, the study of the influence of Norman theory on the origin of law in Ancient Russia, the study of the origin of "Russian Truth", the study of religious influence on the law in Ancient Russia. In general, the study of the origin of law in Ancient Russia in the Chinese scientific community is still relatively weak. The study of the origin of law in Ancient Russia helps to get answers to the origin of the Old Russian state and civilization, the formation of an ethnic group, to enrich and expand the historical horizon. The study of Russian law, its deep understanding and understanding of its uniqueness, stimulated the Chinese scientific community to study the specifics of the Russian legal language, legal thinking, philosophy of law.
\end{abstract}

Keywords: right in Ancient Rus; origin of law; Russian Truth; Norman theory.

\section{1. Исследование происхожАения права на $\triangle$ ревней Руси советскими и российскими учеными}

\section{1. Общие сведения}

В России изучение происхождения права на Древней Руси было впервые начато в рамках макроисторического изучения происхождения древнерусских стран и цивилизаций. C середины XVIII века, при сопоставлении археологических документов, под влиянием ученых по правоведению Императорской Российской академии

\begin{abstract}
Юэ Цян
Замначальника Центра обмена и сотрудничества при Комиссии по юридическим услугам для ШОС(Китай);

Старший преподаватель, Шанхайский политико-

юридический университет; Н.с., Восточно-китайский политико-юридический университет, Китай, г. Шанхай yueqiang850510@sina.com
\end{abstract}

Аннотация. После рассмотрения более 200 репрезентативных исследований юридической литературы, начиная с 19 века, касающихся изучения происхождении права на Древней Руси, можно отметить, что ученые делали упор на четырех моментах: изучение литературы по праву в Древней Руси, изучение влияния норманской теории на происхождение права на Древней Руси, изучение происхождения «Русской Правды», изучение религиозного влияния на право в Древней Руси. В целом изучение происхождения права на Древней Руси в китайском научном сообществе все еще относительно слабо. Изучение происхождения права на Древней Руси способствует получению ответов на происхождение Древнерусского государства и цивилизации, формирование этноса, обогатить и расширить исторический кругозор. Изучение российского права, глубокое его понимание и осмысление уникальности, стимулировало китайское научное сообщество к изучению специфики русского юридического языка, правового мышления, философии права.

Ключевые слова: право на Древней Руси; происхождения права; Русская Правда; Норманская теория.

и историков, стали появляться результаты исследований в части происхождения права на Древней Руси: история русского права (1882-1883), древнейшее русское право (1835), история российских гражданских законов (1845). В силу разных причин дискуссия между западными и славянскими школами в России о норманнской-антинорманнской теории, оказывала влияние на идеи ранних историков права.

Влияние идеологии советского периода, и главенство антинорманской школы «Южного (Южнорусского) происхождения» - оказало значительное влияние на ос-

' Статья подготовлена в рамках «Проекта научных исследований Центра международной юридической подготовки и сотрудничества для ШОС (Китай)» (номер проекта: 20SHJD043, SHPXG202018); «Проекта научных исследований для молодых учёных» Шанхайского политико-юридического университета. 
новные академические позиции историко-правовых исследователей. Наиболее известными исследованиями того времени можно назвать: «Из социально-экономической истории западноевропейского средневековья (1960)», «Российское законодательство X-XX вв.», «Законодательство Древней Руси (1984)».

После распада в 1991 году Советского Союза, изучение древнерусского права избавилось от идеологических барьеров, что дало толчок к дальнейшему развитию поднимаемого в статье темы, появлялись сотни разных школ, взглядов, при этом качество академических достижений все еще требовало дальнейшего совершенствования.

В 21-го веке, с развитием археологии, некоторые исторические взгляды были пересмотрены или скорректированы, стали появляться новые труды. Институт исторических наук РАН, Институт государства и права РАН, Юридический факультет и Исторический факультет МГУ, Исторический факультет СПБГУ - передовые академические заведения, на базе которых были сделаны исследования, касающиеся происхождения права на Древней Руси.

\section{2. Исследование древнерусской юридической литературы}

Покойный профессор исторического факультета МГУ щапов Я.Н. в своей книге «Княжеские уставы и церковь в древней Руси» (1972) проанализировал большое количество юридических документов (княжеские и церковные уставы) по истории Древней Руси XI-XIV вв.

По причине тесной связи государства и церкви, характерной для русского средневековья, как и для других стран Европы, было характерно существование наряду со светской государственной властью и церковной власти, представленной митрополитом, епископами. И те, и другие были господствующим классом и осуществляли некоторые функции управления и суда (Щапов Я.Н. 1972: 3). Далее автор отмечает, что древнерусские княжеские уставы представляют собой источник, освещающий целый ряд важных явлений истории Руси. В княжеских уставах автором были изучены и исторические вопросы взаимоотношения русского общества и власти церкви. Дальнейшие исследования древнерусской юридической литературы во многом связаны с научными работами Щапова Я.Н.

\section{3. Исследования влияния норманской теории на теорию происхождения права на Древней Руси}

Наиболее яркими исследователи русского права XIX века можно назвать Штрубе де Пьермонт, Байер Г.С.,
Миллер Г.Ф., Шлецер А.Л.Фактически, одним из первых норманскую концепцию происхождения «Русской Правды» обосновал Штрубе де Пьермонт. По его мнению, поскольку первые князья Древнерусского государства были варягами, то «естественно думать, что скандинавская нация не преминула ввести свои законы в государстве, в котором она стала господствовать». Как считал Штрубе, у восточных славян было свое право и до призвания князей, но это право оказалось не в силах противостоять новому порядку. По мнению Штрубе, призванные варяги - «русичи», получив в свои руки политическую власть, стали вводить свои племенные законы, как это обычно они делали на всех подконтрольных им территориях. Подверждению своим мыслям он нашел при сравнении «Русской Правды» с законами скандинавских народов - шведов, датчан и др., законы которых, по его мнению, служили не только образцом для составления «Русской Правды», но и источником, откуда непосредственно заимствовались указы.

\section{4. Происхождение «Русской Правды»}

Норманнская теория всегда оказывала глубокое влияние на суждения академического сообщества о происхождении «Русской Правды», являющейся важной вехой в правовом процессе Древней Руси.

Со второй половины 19-го века новый импульс трактовки норманнской теории придает И.Ф.Г. Эверс, приходя в своих исследованиях к умозаключению, что сходство «Русской Правды» со скандинавскими законами «ничего не доказывает», а в основу древнерусских норм положено германское право. Эверс считал основным источником «Русской Правды» и Договоров Руси с Византией иноземное право, главным образом скандинавское и германское. Сходство норм «Русской Правды» с ютландским законом он видел в том, что оба эти памятника права были основаны на источниках германского происхождения, а заимствование из германского первоисточника было возможно, так как между русскими и немцами с незапамятных времен существовали торговые и культурные отношения.

Мнение о германском влиянии поддерживал немецкий ученый К.Л. Гетц, заметивший разительные сходства «Русской Правды» С «Салической Правдой». Он приводил отдельные статьи «Правды», близкие к положениям византийского и германского законодательств. Но эта близость, утверждал он, рассматривая особо каждый случай сходства, не указывает на заимствования или непосредственную зависимость одного памятника от другого. Древнейшая редакция «Русской Правды» в сравнении с «варварскими» Правдами представляется чрезвычайно простым, несложным, несистематическим сборником обычного права, в то время как некоторые «варварские» 
«Правды» характеризуются значительной долей систематичности, детальности в разработке частных форм юридических отношений. Только со временем в русское право входят элементы заимствования, отразившиеся затем в статьях «Краткой Правды».

По мнению ученого П. Дюверпуа «Русская Правда» как законодательный сборник, в значительной степени является законодательным документом князей, в которых содержится ряд положений, касающихся жизни государства Руси, экономической и общественной жизни князей. С развитием феодальных отношений на Руси, уставы князей отражали социально-политические изменения, а также экономические и политические потребности общества того времени, а, следовательно, и необходимость закрепления его законодательства и придания неприкосновенности его собственности. Устав князей определяет статус различных лиц, принадлежащих к роду князей, необходимость обеспечения устойчивой и безопасной экономической системы для определенных категорий граждан (бизнесменов, ростовщиков) и т.д. Он явился источником многих важных правовых положений, созданных князьями, и во многом способствовал становлению правовой системы Древней Руси.

\section{5. О религиозном влиянии права в Древней Руси}

В последние годы все больше ученых склоняются к тому, что при князе Владимире Святославиче Православная церковь стала господствовать на севере. Исторически сложилось, что в разных странах Европы возникновение христианства было обычным явлением, которое расширило власть церкви, позволив ей заниматься государственными делами. Помимо внутренней автономии, церковь обладала юрисдикцией над гражданскими отношениями, основанными на религии. При появлении христианства на Руси, руководящие принципы имели византийские корни, составленными местными законодателями и включенными в Кормчих книгах.

\section{2. ИсслеАования китайских \\ ученых о происхожАении \\ права в $\triangle$ ревней Руси}

В настоящее время в китайском научном сообществе существует незначительное количество научных работ, посвященных изучению происхождения права на Древней Руси, по китайскому индексу научного цитирования опубликовано не более чем 20 трудов ученых в данной области. В целом исследовательская работа китайских ученых в основном сосредоточена на изучении «Русской Правды», изучении происхождения русской национальной цивилизации и этнического происхождения, а также изучении экзогенного влияния русского права.

\section{1. Об исследованиях «Русской Правды»}

«Русская Правда» является важным сводом правовых норм Киевской Руси, ее формирование является важной вехой становления древнерусской правовой системы. Изучение древнерусской правовой истории, идейной истории и даже зарождения русской цивилизации не может быть отделено от данных важных исторических событий. Среди китайских историков, которые занимались изучением «Русской Правды» можно назвать Чжу Хуань и Ван Юэ, результаты их исследований в основном сосредоточены на социальной подоплеке происхождения «Русской Правды». Стоит отметить, что в перевод «Русской Правды» Ван Юэ заложил детальную историческую основу, что позволит проводить дальнейшие исследования.

Ученый Восточно-Китайского Университета политологии и права Ван Хайцзюнь в настоящее время является одним из немногих молодых ученых, специализирующихся на изучении истории российского права, его докторская диссертация (2012) и научно-исследовательские работы направлены на систематическое исследование и оценку «Русская Правда», им сформирована более полная серия результатов исследований по «Русской Правде».

\section{2. Об исследованиях происхождения русского государства, цивилизации и нации}

Ци Цзя, Чжоу Сяохуэй занимались исследованием происхождения древнерусского государства, этнического образования и другие вопросов с точки зрения цивилизации, истории мысли и других более макроперспективных аспектов. В частности, их работы обобщают основные точки зрения советских и российских ученых и имеют долю новаторства в китайском научном сообществе. Между тем, в определенной степени, их труды пронизаны интерпретацией и спекуляцией становления российской правовой мысли. ${ }^{6}$

\section{3. Об исследованиях эффектов влияния экзогенных фактов на формирование русского права}

Интересна точка зрения ученого Ван Сяобо который занимался изучением формирования и происхождения русского права, которое, по его мнению, являлось отражением смешанной правовой культуры, и на формирование древнерусской правовой системы в значительной степени повлияли Византия, Болгария, христианство.?

Исследователь Ван Хайцзюнь выявил влияние римского права на русское право. По его мнению, введение римского права не только создало церковную юрисдик- 
цию в Древней Руси, но и трансформировало русское обычное право и повлияло на правовую систему, касающуюся рабов. Кроме того, проникновение и интеграция римского права в Древнюю Русь осуществлялись через православную церковь, которая также стала средством проникновения римского права в Древнюю Русь.

Рассматривая результаты китайских исследований, можно отметить следующее:

во-первых, результаты были в значительной степени основаны на вводных и обзорных работах ученых разных стран, работы которых имели «фрагментарную» и «точечную» направленность, в результате чего не сумевших осуществить последовательное и углубленное исследование;

во-вторых, количество научных работ по изучению формирования права на Древней Руси достояно мало, отсутствие некоторых исторических данных делает соответствующие исследования несколько однобокими и ограниченными.

\section{3. Перспективы изучения происхожАения $\Delta$ ревнерусского права в Китае}

\section{1. Теоретические исследовании происхождения права Древней Руси}

На основе существующих исследований китайских и зарубежных ученых по данной проблеме в сочетании с большим количеством исторических документов проводится всестороннее и систематическое изучение «норманнско-антинорманнской» теории, которая глубоко затрагивает происхождение древнерусского права, и в то же время проводится сопоставление византийской, европейской и других теорий происхождения древнерусского права.

\section{2. Археологические исследования происхождения древнерусского права}

Опираясь на древнерусскую юридическую исследовательскую литературу, переводятся различные варианты Древнерусских княжеских уставов, проводится их сопоставление; по хронологическому порядку осуществляется систематическое изучение и перевод уставов наиболее влиятельных княжеств Древней Руси, таких как Владимирское, Ярославское, Смоленское, Новгородское.

\section{3. Исследование «Русской Правды»}

Основным документом, которым пользуются при изучении древнерусского права является «Русская Правда». Учеными анализируются различные взгляды российских историков права, применяются новейшие достижения современных китайских и зарубежных исследователей права, обсуждаются происхождение Краткой редакции и более полной и распространенной редакции «Русской Правды», формируются выводы исследования.

\section{4. Ценность и Значимость исслеАОваний}

В силу исторических причин на построение современной правовой системы Китая, в определенной степени, оказало влияние Советское право, и в настоящее время отношения между Китаем и Россией, как отношения всеобъемлющего партнерства и стратегического взаимодействия, вступили в новую эпоху. Изучение древнерусского права имеет положительное значение для обеих сторон и построения правовой системы.

С точки зрения археологической науки систематическое сопоставление, перевод и оценка важных правовых норм княжеств, существовавших на Древней Руси до и во время действия «Русской Правды» помогают прояснить происхождение «Русской Правды», обогатить имеющиеся результаты исследований, а также помогают переосмыслить ценность и значение «Русской Правды».

Изучение происхождения древнерусского права помогает переосмыслить историю, происхождение цивилизации, образование нации. Соединение литературных исторических, лингвистических и археологических материалов способствует расширению кругозора о формировании права на Древней Руси.

Совершенствование исследований российского права, понимание уникальности российского права способствуют стимулированию китайского научного сообщества к изучению русского юридического языка, русского права, русской правовой философии и других научных отраслей.

\section{ЛИТЕРАТУРА}

1. Щапов Я.Н. Княжеские уставы и церковь в древней Руси. - M, 1972.

2. Агафонов А.В. Происхождение и источники древнерусского права (VI - XII вв.): автореф. дис. на соиск. учен. степ. канд. юрид. наук: специальность 12.00.01 / Агафонов Андрей Викторович; [Казан. гос. ун-т им. В.И. Ульянова-Ленина]. Казань, 2006. — 21, 
3. Дювернуа Н.Л. Источники права и суд в древней России. Опыты по истории русского гражданского права. М.: Издательство Юрайт, 2018. 283 с.

4. Перевод Чжу Хуаня и других, Хроники прошлых лет (Первая летопись Древней Руси) (китайский перевод шедевров) [M]. The Commercial Press, 2018.

5. Перевод и аннотация Ван Юэ. Перевод и аннотация «кода Росса» [M], Lanzhou University Press, 1987.

6. Ци Цзя, Цао Вэйань. Происхождение названия «Рось» и формирование страны древней Руси [Дж.] // Исторические исследования, 2012.

7. Ван Сяобо. Происхождение российской правовой системы [Дж.] // Российские исследования, 2008.

8. Ван Хайцзюнь. Исторический памятник российского права — «Русский Кодекс» [N] // Legal Daily, 2016.

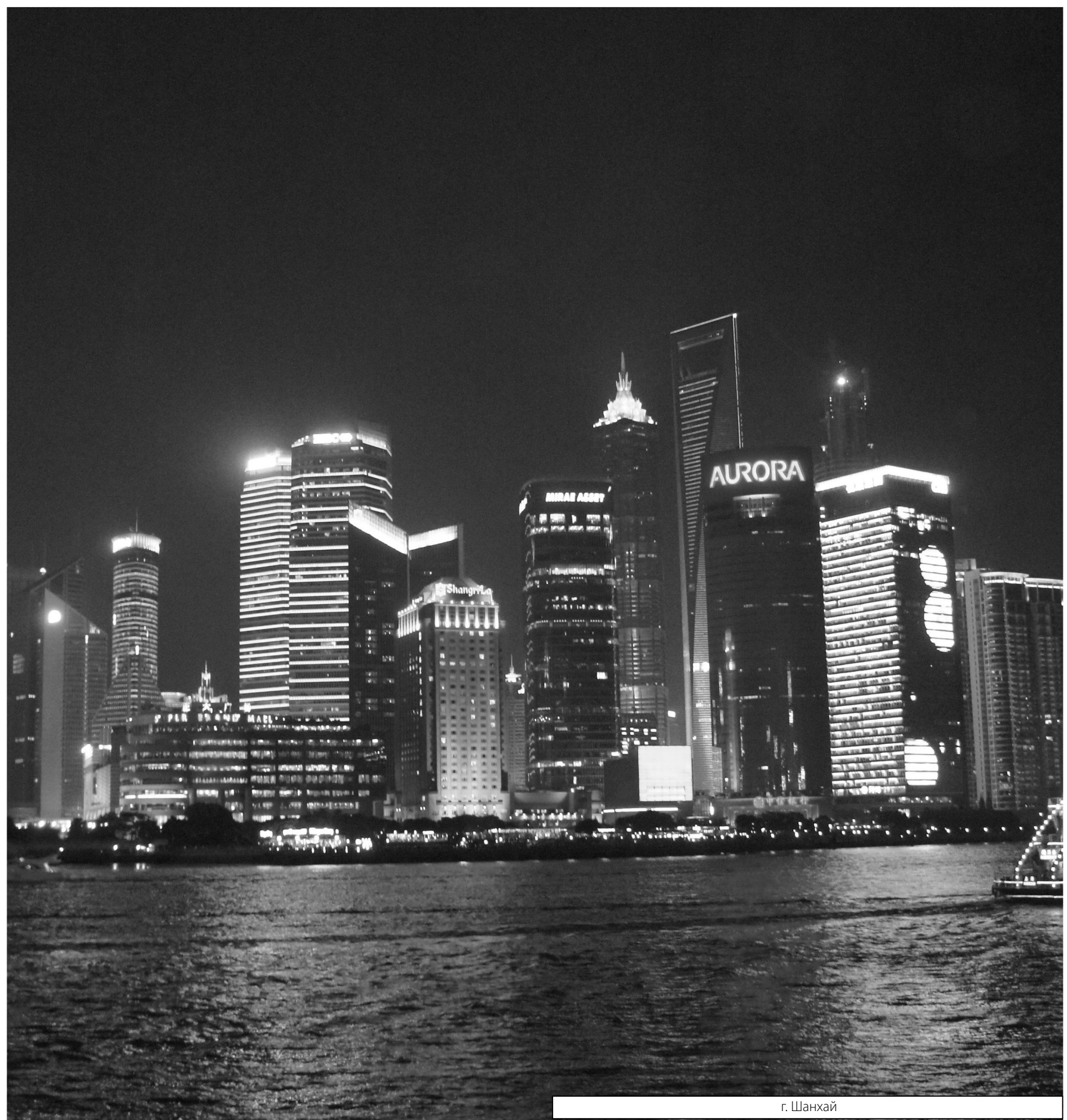

